\title{
Gestation lengths of Finnhorse and Standardbred mares in Finland: effects of breeding season and reproductive status
}

\author{
Tiina Reilas', Anna-Maija Virtala ${ }^{2}$ and Terttu Katila ${ }^{3}$ \\ ${ }^{1}$ MTT Agrifood Research Finland, Ypäiä (Finland) \\ 2 Department of Basic Veterinary Sciences, University of Helsinki, Helsinki (Finland) \\ ${ }^{3}$ Department of Production Animal Medicine, University of Helsinki, Saarentaus (Finland)
}

\begin{abstract}
Summary: The aim of this study was to investigate factors influencing the gestation length (GL) in Finnhorses (FH) and in American Standardbreds (SB), with particular emphasis on the effect of the mare's reproductive status. Data including 15 breeding seasons (1991-2005) was obtained from Suomen Hippos, the Finnish trotting and breeding association. From the records, 8952 pregnancies in 3649 SB mares and 4579 pregnancies in $2149 \mathrm{FH}$ mares fulfilled the inclusion criteria: artificial insemination (Al) using either fresh or transported semen, a viable foal, and a GL of 300-390 days (last Al-parturition). The effects of breed, mare age and reproductive status (maiden, barren, rested or foaled) at the beginning of the mating season, parity, month and year of mating, stallion station, and sex of the foal on GL were estimated using linear mixed models. All models were fitted using the residual maximum likelihood estimation method. The $\mathrm{GL}$ in foaled mares was significantly shorter than in maiden, barren or rested mares (SB: $\mathrm{P}<0.0001 ; \mathrm{FH}: \mathrm{P}<0.01)$. In maiden, barren and rested mares, the GLs were similar. The mating month had a significant effect on the $\mathrm{GL}(\mathrm{P}<0.0001)$. The longest and shortest gestations were found in mares mated in April and August, respectively. The SB mares mated in February-March had shorter pregnancies than mares mated in April $(\mathrm{P}<0.01$ ). The $\mathrm{FH}$ mares carried their foals significantly longer (adjusted mean 334.8 days, $95 \% \mathrm{Cl} 334.2-335.5$ ) than SB mares (adjusted mean 331.7 days, $95 \% \mathrm{Cl} 331.2-332.3$ days) $(\mathrm{P}<0.0001)$. In both breeds, primiparous mares had longer gestations than multiparous mares $(\mathrm{P}<0.0001)$. The $\mathrm{GL}$ between different age groups did not differ in the $\mathrm{SB}$, but young $\mathrm{FH}$ mares had 2.3 days shorter gestation than very old mares $(P<0.05)$. Colt foals were carried 1.8 days longer than fillies in both breeds $(P<0.0001)$. In conclusion, the relationship between mating date and gestation length in Standardbred mares was positive from March to April and negative from April to August. A short mean GL of the SB mares in Finland supports the influence of latitude on GL. Reproductive status of the mare at the time of Al had a significant effect on the GL. This finding suggests that the uterine environment in early pregnancy may affect the length of gestation.
\end{abstract}

Keywords: horse / gestation length / pregnancy / latitude / season / reproduction

Correspondence: Tiina Reilas, DVM, PhD, MTT Agrifood Research Finland, Animal Production Research, Opistontie 10 A 1, 32100 Ypäiä, Finland. E-Mail: tiina.reilas@mtt.fi

Citation: Reilas T., Virtala A.-M., Katila T. (2014) Gestation lengths of Finnhorse and Standardbred mares in Finland: effects of breeding season and reproductive status. Pferdeheilkunde 30, 45-51

\section{Introduction}

Gestation length (GL) for various horse breeds average from 332 to 345 days (Bos and Van der May 1980, Marteniuk et al. 1998, Davies Morel et al. 2002, Pérez et al. 2003, Valera et al. 2006, Winter et al. 2007, Cilek 2009, Satué et al. 2011 a, McCue and Ferris 2012, Aoki et al. 2013). Variation in the GL resulting in viable foals is very high; ranges of $45 \pm 7$ days have been reported for Thoroughbred, Criollo and heavy draft mares (Hintz et al. 1992, Winter et al. 2007, Aoki et al. 2013) and $75 \pm 7$ days for Standardbred, Thoroughbred, Carthusian and Andalusian mares (Marteniuk et al. 1998, Davies Morel et al. 2002, Pérez et al. 2003, Valera et al. 2006, McCue and Ferris 2012). Gestation lengths of 302-383 days and 315-388 days have resulted in viable foals in Standardbreds (Marteniuk et al. 1998) and Thoroughbreds (Davies Morel et al. 2002), respectively. Based on literature review, Vandeplassche (1986) summarized that in $93 \%$ of mares delivering viable foals gestation lasted $320-350$ days and about $1 \%$ of mares had excessively prolonged gestations (>370 days). Foals born before 300 days are considered non-viable (Rossdale 1976) but occasionally some manage to survive normally (Valera et al. 2006).
Several factors have been reported to influence the $G L$ in the mare. According to Davies More/ et al. (2002) these factors can be considered as fetal, maternal or environmental in origin. Genetic aspects of the GL have been investigated in many studies (Rollins and Howell 1951, Marteniuk et al. 1998, Valera et al. 2006, Cilek 2009, Langlois and Blouin 2012, Kuhlet al. 2013). Foetal gender is the best-known factor affecting the GL: a longer gestation for colt than for filly foals has been known for long (Lehndorff 1925, Uppenborn 1933). The effects of maternal age or parity on the $G L$ are less consistent. In some studies, mare age had no effect on GL (Davies Morel et al. 2002, McCue and Ferris 2012), in others the GL increased with age (Elliott et al. 2009, Langlois and Blovin 2012) or longer gestations were observed in both younger and older mares compared to middle-aged mares (Valera et al. 2006, Cilek 2009). According to some reports, the parity did not influence the GL (Elliott et al. 2009, Dicken et al. 2012). Other researchers have found longer gestations in primiparous mares than in multiparous mares (Pool-Anderson et al. 1994, Satué et al. 2011 a). Other maternal factors are less well documented. The effect of the mare status on the GL has been investigated in one study; Langlois and Blouin 
(2012) found that mares which did not foal the preceding year showed longer gestations than mares with a foal at foot (Langlois and Blovin 2012).

Mating season is the most important environmental factor affecting the $G L$ in mares (Howell and Rollins 1951). Many studies have shown that the gestation length shortens as the breeding season progresses (Satué et al. 2011b). However, short gestations have also been observed in mares bred early in the breeding season (Howell and Rollins 1951, Hintz et al. 1992, Davies Morel et al. 2002). It is evident that horses have mechanisms by which they adapt to seasonally varying environment. Seasonal variation in the length of daylight has been suggested to act as a cue for this gestation length adjustment (Howell and Rollins 1951). Some researchers have suggested that latitude influences GL (Satué et al. 2011 b, Dicken et al. 2012). Gestation lengths of Standardbred mares have been studied at low latitudes (Marteniuk et al. 1998, Dicken et al. 2012). Finland is one of the world's northernmost countries lying between latitudes $60^{\circ}$ and $70^{\circ} \mathrm{N}$. The Nordic location and a population of 25000 SB horses gave us a reason to examine the GL of SB mares in Finland.

Gestation lengths are of interest as breeders want to have early foals, watch over the foalings and maintain a 12 months' foaling interval. Since the official birthday of all horses in the northern hemisphere is January 1st, most horse breeders wish to have early foals which are as mature as possible when they reach their first birthday. Pressure for early foals leads to matings in early spring. Although the breeding management of transitional mares can be challenging for the veterinarian and the stud manager, the pregnancy rates following the first ovulation of the year do not differ from those in subsequent ovulations (Cuervo-Arango and Clark 2010). A gestation length longer than the average is to be expected from early conception. Season is the main reason for the long gestation, but the effect of the mare's reproductive status is unclear.

The aim of this study was to investigate factors influencing the gestation length in Finnhorses and in the Finnish population of American Standardbreds. By determining the mean gestation length of the Standardbreds at high latitudes, we hoped to gain some light on the possible role of latitude on GL. The effect of the mares' reproductive status on GL was of particular interest in this study, since there is a paucity of reports on this maternal factor.

\section{Material and methods}

The data originate from all reported matings (the database of Suomen Hippos, the Finnish trotting and breeding association) of the American Standardbred (SB) trotter mares and the Finnhorse (FH) mares in Finland (between latitudes $60^{\circ} \mathrm{N}$ and $70^{\circ} \mathrm{N}$ ) during 1991-2005 (Katila et al. 2010). From these records, 8952 pregnancies in 3649 SB mares and 4579 pregnancies in $2149 \mathrm{FH}$ mares fulfilled the inclusion criteria: artificial insemination (Al) using either fresh or transported semen, a viable foal, the mare occurring the first time in the data as a maiden, and gestation length of 300-390 days. The gestation lengths were calculated as the time from the last $\mathrm{Al}$ to the parturition.
The Finnish cold blood, the Finnhorse, is of universal type and is mostly used for sports. Its average height at withers is $156 \mathrm{~cm}$ and the weight is $550 \mathrm{~kg}$. The monthly distributions of conceptions are presented in Fig. 1. Due to the small number of breedings, early and late mating months were combined for data analysis: February-March in SB, March-April in FH and August-October in both breeds.

The mares were divided into four age groups: young (2-9 years), middle-aged ( $10-13$ years), ageing ( $14-16$ years), and very old ( $\geq 17$ years). The mare's status at the time of $\mathrm{Al}$ was 1) maiden (never mated), 2) barren (mated earlier, but aborted or did not conceive), 3) rested (not mated after the last foaling), or 4) foaled (mare with a live or dead full term foal). The parity was categorized into $1,2-5$ and $6-13$ foalings. The size of the stallion station was divided into four groups: < 10, 10-39, 40-99, and $\geq 100$ mares/year. The year of mating was categorized as 1991-1994, 1995-1998, 1999-2002, and 2003-2005.

The statistical analyses were performed using the Mixed procedure of the SAS System for Windows, version 9.3 (SAS Institute Inc., Cary, NC, USA). The association of factors with GL was estimated using linear mixed models. Models included the fixed effects of mating month, year, size of the stallion station, mare status and age, and foal gender. The influences of mare and stallion were analyzed as random effects in models. The effect of parity was evaluated separately using a model where the mare status was excluded due to multicollinearity between parity and mare status. Both breeds were first analyzed separately and then together to estimate the difference in $\mathrm{GL}$ between the two breeds. P-values and confidence intervals were adjusted with Tukey's method in pairwise comparisons of categorical variables. All models were fitted using the residual maximum likelihood estimation method. The data are presented as adjusted means and $95 \%$ confidence intervals (Cl) of the means, or means $\pm 95 \% \mathrm{Cl}$. P-values less than 0.05 were considered statistically significant.

\section{Results}

Finnhorse mares carried their foals significantly longer (adjusted mean 334.8 days, $95 \% \mathrm{Cl} 334.2-335.5$ ) than SB mares (adjusted mean 331.7 days, $95 \% \mathrm{Cl} 331.2-332.3$ days) $(\mathrm{P}<0.0001)$. The intraclass correlation coefficient (ICC) for the random effect of the mare was $39.7 \%$ for $\mathrm{FH}$ and $33.0 \%$ for SB. For the FH and the SB stallions, ICC values were $2.8 \%$ and $4.2 \%$, respectively. The distributions of the $\mathrm{GL}$ are presented in Fig 2. Gestation lasted 321-350 days in $87.4 \%$ of the $\mathrm{FH}$ and $85.5 \%$ of the SB mares. The frequencies of relatively short gestations (31 $1-320$ days) were $7.2 \%$ in the $\mathrm{FH}$ and $10.7 \%$ in the SB.

The effect of the mare's reproductive status on GL was statistically significant in both breeds $(P<0.0001)$. The $G L$ in foaled mares was significantly shorter than in maiden, barren or rested mares (Table 1). The difference between mare statuses was greatest in April and decreased thereafter (Fig. 3 and 4). The GL was similar in maiden, barren and rested mares.

The mating month had a significant effect on $G L(P<0.0001)$. The longest and shortest gestations were found in mares 
mated in April and August, respectively (Fig. 5). The decrease in adjusted means from April to August was 11.9 days in the SB mares and 14.3 days in the FH mares. SB mares mated in February-March had shorter pregnancies than mares mated in April $(\mathrm{P}<0.01)$. The mating month had a similar effect on gestation length in all mare statuses (Fig. 3 and 4).

The mating year had a significant effect on $\mathrm{GL}$ in the $\mathrm{FH}$ $(P<0.001)$ but not in the SB. The parity status had a significant effect on $G L$ in both breeds $(P<0.0001)$. Primiparous mares had longer gestations than multiparous mares (Table 1). Young FH mares had 2.3 days shorter gestation as compared to very old mares $(P<0.05)$, but in the SB age groups the $G L$ did not differ. Foal gender had a significant effect on $G L(P<0.0001)$. The colts were carried 1.8 days longer than the fillies in both breeds $(P<0.0001)$.

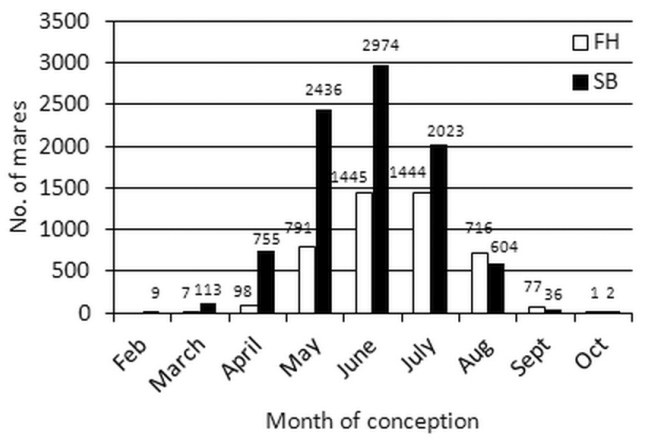

Fig. 1 - Monthly distribution of the conceptions in the Finnhorse (FH) and the Standardbred (SB) mares. / Monatliche Verteilung der Konzeption bei Finnpferden (FH) und Standardbreds (SB)

\section{Discussion}

Reproductive status of the mare

The GL of foaled mares was significantly shorter than the $G L$ of mares of other reproductive statuses. This is in agreement with Langlois and Blovin (2012) who reported longer gestations for mares which had not foaled the preceding year. In our study, the difference in GLs was greatest in SB mares mated in April (4.5 days) and in FH mares mated in May (3.7 days), and decreased thereafter. Since the foaled mares differ from the maiden, barren and rested mares especially during the early pregnancy, the possible differences in GLs are likely to originate from this time. The post partum uterine environment may favor conceptus growth. On the other hand, the endometrium of some maiden, barren and rested mares may not provide optimal conditions for conceptus

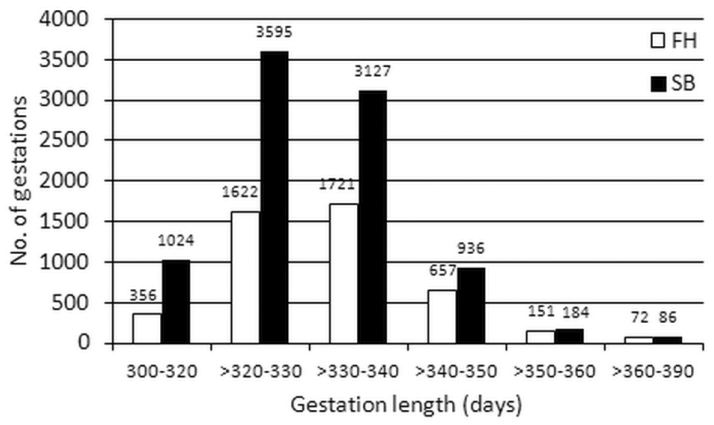

Fig. 2 - Distribution of gestation lengths in the Finnhorse (FH) and the Standardbred (SB) mares. / Verteilung der Trächtigkeitslängen bei Finnpferden (FH) und Standardbreds (SB)

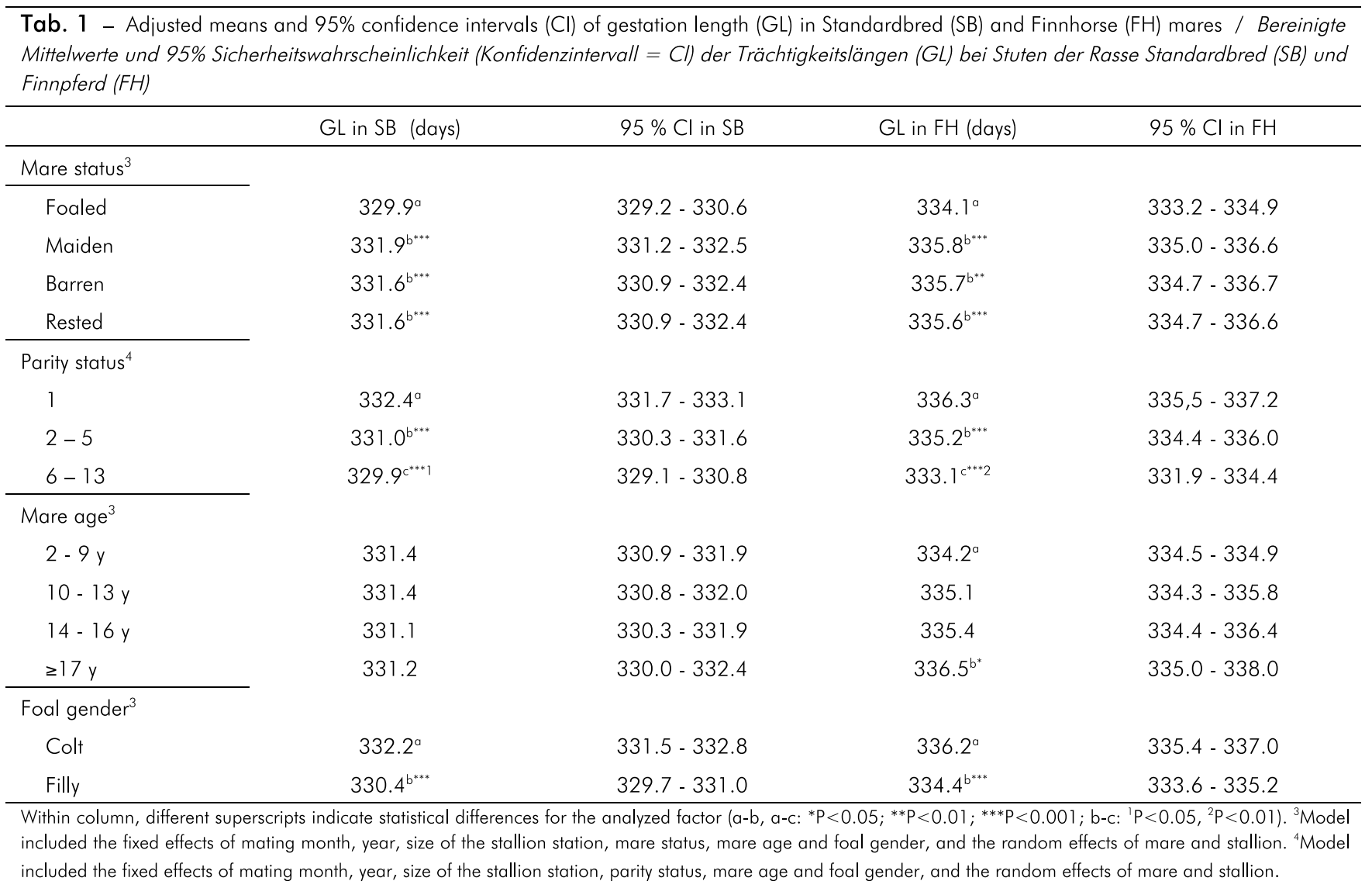




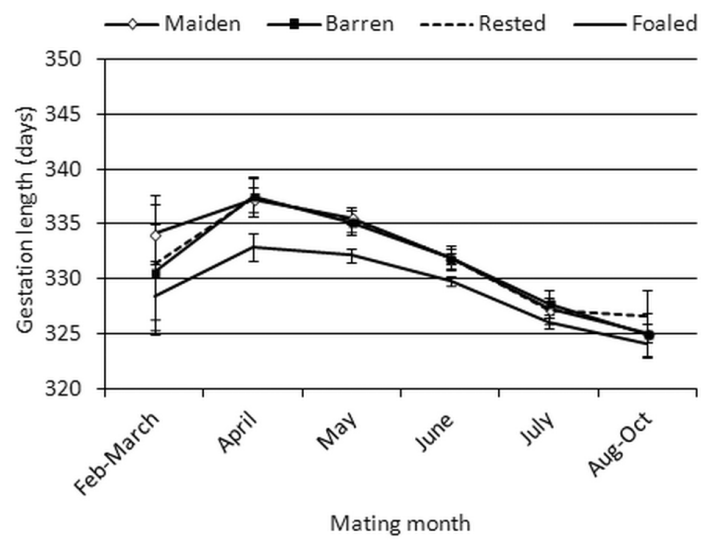

Fig. 3 - Mean gestation length $( \pm 95 \% \mathrm{Cl})$ in the Standardbred mares by the mating month and the mare status. / Mittlere Trächtigkeitslänge $( \pm 95 \% \mathrm{Cl})$ bei Standardbreds in Abhängigkeit vom Besamungsmonat und Reproduktionsstatus der Stute

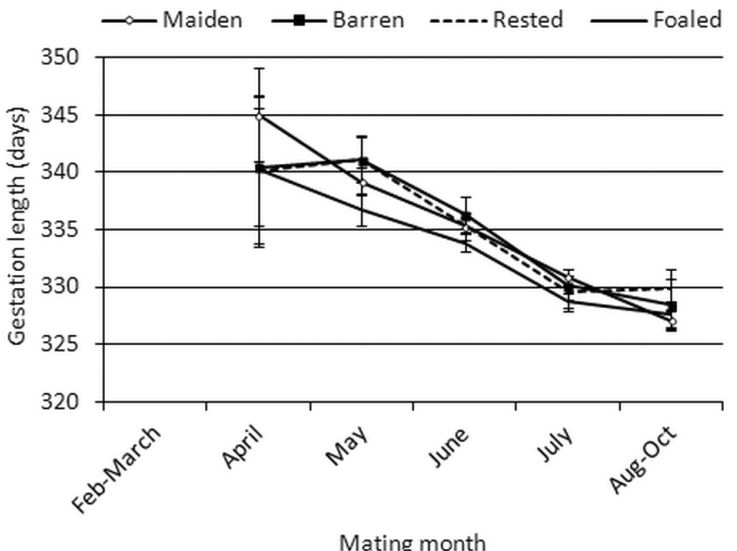

Fig. 4 - Mean gestation length $( \pm 95 \% \mathrm{Cl})$ in the Finnhorse mares by the mating month and the mare status. Seven mares bred in March are not included in the graph. / Mittlere Trächtigkeitslänge ( $\pm 95 \%$ CI) bei Finnpferden in Abhängigkeit vom Besamungsmonat und Reproduktionsstatus der Stute. Sieben Stuten, die im März besamt worden waren, sind nicht in der Grafik enthalten.

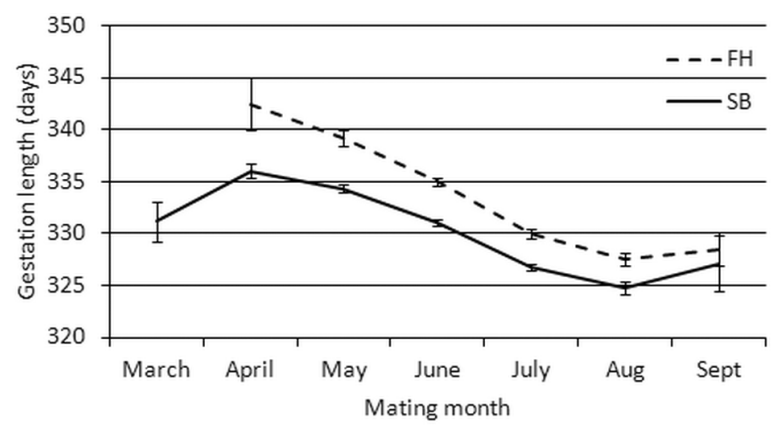

Fig. 5 - Mean gestation length $( \pm 95 \% \mathrm{Cl})$ in the Finnhorse $(\mathrm{FH})$ and the Standardbred (SB) mares. / Mittlere Trächtigkeits/änge ( $\pm 95 \%$ CI) bei Finnpferden (FH) und bei Standardbreds (SB) development, particularly soon after recovery from winter anoestrus.

In Finland, the breeding season starts in April (SB) and May (FH) and extends into August, with a peak around the summer solstice in June. Koskinen and Katila (1991) showed that anoestrous Finnhorses started to cycle a month later than Standardbreds. In FH, the three-year olds and the brood mares were all anoestrous during winter and started to cycle on average before the middle of May. Anoestrous mares in training, both $\mathrm{FH}$ and $\mathrm{SB}$, began to cycle before the middle of April. More than $25 \%$ of mares in training were cyclic in January. In the present study, mares mated in March (SB) or April $(\mathrm{FH})$ may have cycled through the winter. Consequently, many of the maiden, barren and rested mares mated in April (SB) or May (FH) must have conceived soon after they started to cycle.

In the early spring, mares may have various degrees of residual endometrial atrophy even after having had one or more ovulatory cycles (Kenney and Doig 1986). In spite of atrophic endometrium, these mares can become pregnant (Kenney 1978). Pregnancy rates resulting from the first ovulation are believed to be lower than in subsequent ovulations, but Cuervo-Arango and Clark (2010) failed to show significant differences, perhaps due to the small number of mares. To our knowledge, gestation lengths of mares conceiving in their first oestrus of the season have not been reported. It is possiblethat secretions from slightly atrophic endometrial glands do not support optimal conceptus growth.

Vandeplassche (1986) reported delayed secretion of equine chorionic gonadotropin (eCG) in five mares with prolonged gestation and suggested that some equine pregnancies are prolonged due to a delay in embryonic growth within the first two months. He also hypothesized that exceptionally low levels of progesterone under certain circumstances (before day 40) could induce a retardation of embryonic growth. Progesterone has been shown to regulate conceptus growth and development in cattle and sheep. Exogenous progesterone during the first four days of pregnancy increased morphological development of Day-14 bovine conceptuses and altered secretory activity of uterine endometrium (Garrett et al. 1988). Similarly, progesterone supplementation to ewes during the first three days of pregnancy was shown to enhance foetal growth at mid-gestation (Kleemann et al. 1994). Progesterone receptors have been demonstrated in the early equine embryo (Rambags et al. 2008). Equine embryo transfers to asynchronous uteri have demonstrated the importance of an appropriate uterine environment for embryo growth (Wilsher et al. 2012). These studies emphasize the importance of histotrophe to embryonic growth. It is possible that a suboptimal uterine environment in early pregnancy accounts for some differences in GL.

\section{Mare age, parity and foal gender}

In the present study, GL was the same in all age groups of SB mares. This is in agreement with previous works on Thoroughbreds (Davies Morel et al. 2002, McCue and Ferris 2012) and Standardbreds (Dicken et al. 2012). However, very old FH mares exhibited 2.3 days longer gestations than young mares. 
Langlois and Blovin (2012) analyzed substancial data of ten breeds without including parity and found an almost linear increase of GL with age. GL was nearly four days longer in the oldest mares as compared to the youngest. Similarly, Elliott et al. (2009) reported that $G L$ increased with age.

This study confirms previous findings that primiparous mares have slightly longer gestations than multiparous mares. Others have reported even 10 (Pool-Anderson et al. 1994) or 14.5 (Satué et al. 2011 a) days longer GL in primiparous mares compared to multiparous mares. In the study of Valera et al. (2006), GL first decreased and then, after the 4th or 5th parturition, lengthened progressively. However, after adjusting for age, Elliott et al. (2009) found no significant association between GL and parity. Wilsher and Allen (2003) discovered that primiparous mares gave birth to significantly smaller foals than multiparous mares. The same study revealed that mare age and parity influenced the development of the placenta; density of the placental microcotyledons was lower in primiparous mares than in young multiparous mares, and lowest in aged multiparous mares. Elliott et al. (2009) confirmed that parity, but not GL, was significantly associated with foal birth weight and placental weight. Thus, placental size and function in primiparous mares may be responsible for slower intrauterine growth and longer gestation.

The sex of the foetus is generally known to affect the gestation length, but the reason is unclear. The 1.8-days longer gestation length for colts agrees with previous works: 1.2-1.8 days (Uppenborn 1933, Bos and Van Der May 1980, Sevinga et al. 2004, Cilek 2009, Langlois and Blouin 2012) and 2-2.5 days (Marteniuk et al. 1998, Pérez et al. 2003, Valera et al. 2006, Dicken et al. 2012). In some studies, even larger differences have been reported (Davies Morel et al. 2002, Satué et al. 201 1a, Aoki et al. 2013).

\section{Season}

Mating season is the most important environmental factor affecting the GL of mares (Howell and Rollins 1951). The GL in the present study shortened as the breeding season progressed, as shown in many studies (Satué et al. 2011b). However, mating in March resulted in shorter GL than mating in April and the GL started to decline first after April. Short gestations observed in mares bred in March agree with some previous studies (Howell and Rollins 1951, Langlois and Blovin 2012) and fit to a wavelike year pattern (Cohen 1970). The large material in our study and in the French study (Langlois and Blovin 2012) confirm that the culmination point is in April and the nadir probably in August. The average decrease in GL of 3 days per month in Finnish SB mares is in agreement with several other reports (Marteniuk et al. 1998, Pérez et al. 2003, Valera et al. 2006). The shape of the curve outside the breeding season is less well documented probably due to small numbers of mares (Howell and Rollins 1951) or false declarations of birth (Langlois and Blovin 2012). Langlois and Blovin (2012) reported an increase of GL in mares mated in September and October and a decrease in November and December. The authors suggested that there is a second wave in autumn. However, a one wave pattern seems more likely due to the photoperiodic control of reproduction (Cohen 1970).
Although daylight changes were suggested to influence the monthly variation of equine GL decades ago (Howell and Rollins 1951), the precise mechanisms are still not known. The increase in day length most likely exerts its effects on foetal maturation rate at the end of pregnancy. Exposure of pregnant mares to artificially extended day length from December 1 st has been shown to shorten the GL by 10 days (Hodge et al. 1982). In the present study, only one month of increasing day length after March equinox seemed sufficient to significantly decrease the GL of mares foaling in April compared to those foaling in March. The increasing day length from December solstice to March equinox did not shorten, however, the GL of SB mares foaling in March. The day lengths before March equinox may have been too short to stimulate these mares.

If the GLs follow a one wave pattern, they start to get longer in the fall probably due to increasing night length. In the horse, as in other animals, photoperiod controls melatonin secretion from the pineal gland: levels are high during the dark phases and low during the light period (Palmer and Guillaume 1992). Thus, the foetus is exposed to circadian and circannual rhythms of melatonin. Melatonin receptors have been identified in foetal tissues of several species, e.g., short-day breeders like sheep (Helliwell and Williams 1994, Torres-Farfan et al. 2008) and red deer (Williams et al. 1997). Williams et al. (1997) suggested that melatonin is involved in foetal growth and development. According to Torres-Farfan et al. (2008) melatonin directly inhibits cortisol production by the foetal adrenal gland of sheep. Cortisol secreted by foetal adrenals at the end of pregnancy is responsible for organ maturation in many species (Liggins 1994). In the foetal foal, unlike in the foetal lamb, the cortisol surge occurs very close to term (Fowden and Silver 1995). TorresFarfan et al. (2008) proposed that melatonin prevents major contraction of cerebral vessels, restrains cortisol release and restricts brown adipose tissue lipolysis during foetal life in sheep. The role of melatonin in the physiology of the equine foetus has not been studied, but it is probable that there are melatonin receptors also in equine foetal tissues critical for successful adaptation to postnatal life. Changing melatonin levels could maybe participate in the maturation of the equine foetus and in the regulation of the GL.

\section{Latitude}

Gestation length of the SB in this study (adjusted mean 331.7 days) was shorter than that reported for this breed from other countries: 343.3 days in Michigan (Marteniuk et al. 1998) and 349.1 days in New Zealand (Dicken et al. 2012). However, mating months should be taken into consideration when the GLs in different studies are compared. On monthly basis, the $\mathrm{GL}$ of the SB mares in Finland (latitude $60^{\circ}-70^{\circ} \mathrm{N}$ ) was on average 9 days shorter than the $\mathrm{GL}$ in a Standardbred breeding farm in mid-Michigan (latitude ca. $43^{\circ} \mathrm{N}$ ) (Marteniuk et al. 1998). The difference was 15 days between mares bred in March when day and night are of equal length at all latitudes, and 8 days between mares bred in June. Satué et al. (2011 b) and Dicken et al. (2012) suggested that the latitude may influence GLs. The 20 degrees' difference in the latitude between Finland and Michigan may have accounted, at least in part, for the differences in these SB brood mare 
populations. The days lengthen faster after the December solstice and the day length around the June solstice is longer in Finland than in Michigan. For instance, about $16 \mathrm{~h}$ of day light is reached already at the end of April. At the June solsti$\mathrm{ce}$, the day length is 19 hours or more. In ewes, the magnitude of the reproductive endocrine response is reported to be dependent on the strength of the photoperiodic signal (Robinson and Karsch 1987). Different management and nutrition practices may have also contributed to the different GLs in these countries. Artificial lighting programs are seldom used in Finland, but as horses are stabled until May, lights are needed at feeding times.

\section{Record keeping}

The true gestation length should be calculated from the day of ovulation to the day of foaling (Davies Morel et al. 2002). However, the GL in the present study was measured from the last insemination to the foaling. The true gestation length may have actually been on average 1 to 1.5 days shorter because the $\mathrm{Al}$ and the ultrasound scannings to detect ovulation are performed in Finland every 2 to 3 days. Administrative data in our study and in the French study (Langlois and Blouin 2012) may contain some erroneous declarations of matings or foalings. The Finnish studbooks and horse registers are kept and administered by Suomen Hippos. The stallion managers have to report all matings of the breeding season in October. The mare owners have to report the births first and then register the foals before the 1st of April. If the mating or the birth has not been reported, the foal is not registered and not allowed to race. As a consequence, one can assume that practically all the matings of the trotter mares and births of the foals are reported in Finland. Falsifications of the last mating dates or the foaling dates are unlikely since the dates are published by Suomen Hippos. According to Langlois and Blovin (2012), French breeders often do not declare the date of last mating but only that of the first mating.

\section{Conclusions}

Mating in March resulted in significantly shorter GL than mating in April. A decline in gestation length was observed from April to August. Results of the present study suggest that in Finland the gestation length follows a wavelike year pattern with the culmination point in April and the nadir in August. Finnhorse mares carried their foals significantly longer than SB mares. The mean GL of the SB mares was about two weeks shorter than that reported for SBs from other countries. The short gestation length in this Nordic country supports the influence of latitude on gestation length. The reproductive status of the mare at the time of Al had a significant effect on the GL; the foaled mares had shorter gestations than the maiden, barren or rested mares. This finding suggests that the uterine environment in early pregnancy may affect the length of gestation.

\section{Acknowledgements}

The authors thank the Ministry of Agriculture and Forestry for funding this study, the Suomen Hippos for providing the data, and statistician Tero Vahlberg for the statistical analyses.

\section{References}

Aoki T., Yamakawa K., Ishii M. (2013) Factors affecting gestation length in heavy draft mares. J. Equine Vet. Sci. 33, 437-440

Bos H., Van der May G. J. W. (1980) Length of gestation periods of horses and ponies belonging to different breeds. Livestock Prod. Sci. 7, 181-187

Cilek $S$ (2009) The survey of reproductive success in Arabian horse breeding from 1976-2007 at Anadolu State Farm in Turkey. J. Anim. Vet. Adv. 8, 389-396

Cohen P. (1970) Comparison of seasonal influence on pregnancy duration in man and domestic animals. Int. J. Biometeor. 14, 365369

Cuervo-Arango J., Clark A. (2010) The first ovulation of the breeding season in the mare: The effect of progesterone priming on pregnancy rate and breeding management ( $\mathrm{hCG}$ response rate and number of services per cycle and mare). Anim. Reprod. Sci. 118, 265-269

Davies Morel M. C. G., Newcombe J. R., Holland S. J. (2002) Factors affecting gestation length in the Thoroughbred mare. Anim. Reprod. Sci. 74, 175-185

Dicken M., Gee E. K., Rogers C. W., Mayhew I. G. (2012) Gestation length and occurrence of daytime foaling of Standardbred mares on two stud farms in New Zealand. New Zealand Vet. J. 60, 42-46

Elliott C., Morton J., Chopin J. (2009) Factors affecting foal birth weight in Thoroughbred horses. Theriogenology 71, 683-689

Fowden A. L., Silver M. (1995) Comparative development of the pituitary-adrenal axis in the fetal foal and lamb. Reprod. Dom. Anim. 30, 170-177

Garrett J. E., Geisert R. D., Zavy M. T., Morgan G. L. (1988) Evidence for maternal regulation of early conceptus growth and development in beef cattle. J. Reprod. Fert. 84, 437-446

Helliwell R. J. A, Williams L. M. (1994) The development of melatonin-binding sites in the ovine fetus. J. Endocrinol. 142, 475-484

Hintz H. F., Williams J., Hillman R., Houssay H., Ferrer Reyes R. (1992) Effect of month of breeding on duration of gestation period of Thoroughbreds in Argentina. Equine Practice 14, 16-20

Hodge S. L., Kreidel J. L., Potter G. D., Harms P. G., Fleeger J. L. (1982) Influence of photoperiod on the pregnant and postpartum mare. Am. J. Vet. Res. 43, 1752-1755

Howell C. E., Rollins W. C. (1951) Environmental sources of variation in the gestation length of the horse. J. Anim. Sci. 10, 789-796

Katila T., Reilas T., Nivola K., Peltonen T., Virtala A.-M. (2010) A 15 year survey of reproductive efficiency of Standardbred and Finnhorse trotters in Finland - descriptive results. Acta Vet. Scand. 52, 40 (http://www.actavetscand.com/content/52/1/40)

Kenney R. M. (1978) Cyclic and pathologic changes of the mare endometrium as detected by biopsy, with a note on early embryonic death. J. Am. Vet. Med. Assoc. 172, 241-262

Kenney R. M., Doig P. A. (1986) Equine endometrial biopsy. In: Current therapy in theriogenology, Morrow D.A. Editor, 2nd Ed., WB Saunders, Philadelphia, USA, 723-729

Kleemann D. O., Walker S. K., Seamark R. F. (1994) Enhanced fetal growth in sheep administered progesterone during the first three days of pregnancy. J. Reprod. Fert. 102, 411-417

Koskinen E., Katila T. (1991) Onset of luteal activity in non-foaling mares during the early breeding season in Finland. Acta vet. scand. 32, 319-325

Kuhl J., Wulf M., Aurich C. (2013) Influences on gestational length in Warmblood broodmares. Reprod. Dom. Anim. Suppl. 1. 48, 68-69

Langlois B., Blovin C. (2012) Genetic parameters for gestation length in French horse breeds. Livestock Science 146,133-139

Lehndorff G. G. (1925) Trächtigkeit. A. Trächtigkeitsdaver. In: Handbuch für Pferdezüchter, Verlagsbuchhandlung Paul Parey, Berlin 34-41

Liggins G. C. (1994) The role of cortisol in preparing the fetus for birth. Reprod. Fertil. Dev. 6, 141-150

Marteniuk J. V., Carleton C. L., Lloyd J. W., Shea M. (1998) Association of sex of fetus, sire, month of conception, or year of foaling with duration of gestation in Standardbred mares. J. Am. Vet. Med. Assoc. 212, 1743-1745

McCue P.M., Ferris R. A. (2012) Parturition, dystocia and foal survival: A retrospective study of 1047 births. Equine Vet. J. 44, Suppl. 41, 22-25 
Palmer E., Guillaume D. (1992) Photoperiodism in the equine species - what is a long night? Anim. Reprod. Sci. 28, 21-30

Pérez C. C., Rodríguez l., Mota J., Dorado J., Hidalgo M., Felipe J., Sanz J. (2003) Gestation length in Carthusian Spanishbred mares. Livestock Prod. Sci. 82, 181-187

Pool-Anderson K., Raub R. H., Warren J. A. (1994) Maternal influences on growth and development of full-sibling foals. J. Anim. Sci. 72, 1661-1666

Rambags B. P. B., van Tol H. T. A., van den Eng M. M., Colenbrander B., Stout T. A. E. (2008) Expression of progesterone and oestrogen receptors by early intrauterine equine conceptuses. Theriogenology 69, 366-375

Robinson J. E., Karsch F. J. (1987) Photoperiodic history and a changing melatonin pattern can determine the neuroendocrine response of the ewe to daylength. J. Reprod. Fert. 80, 159-165

Rollins W. C., Howell C. E. (1951) Genetic sources of variation in the gestation length of the horse. J. Anim. Sci. 10, 797-806

Rossdale P. D. (1976) A clinician's view of prematurity and dysmaturity in Thoroughbred foals. Proc. Roy. Soc. Med. 69, 631-632

Satué K., Felipe M., Mota J., Mu oz A. (201 la) Gestational length in Carthusian broodmares: effects of breeding season, foal gender, age of the mare, year of parturition, parity and sire. Polish J. Vet. Sci. 14, 173-180

Satué K., Felipe M., Mota J., Mu oz A. (2011 b) Factors influencing gestational length in mares: A review. Livestock Sci. 136, 287-294

Sevinga M., Barkema H. W., Stryhn H., Hesselink J. W. (2004) Retained placenta in Friesian mares: incidence, and potential risk factors with special emphasis on gestational length. Theriogenology $61,851-859$
Torres-Farfan C., Valenzuela F. J., Mondaca M., Valenzuela G. J., Krause B., Herrera E. A., Riquelme R., Llanos A. J., Seron-Ferre M. (2008) Evidence of a role for melatonin in sheep physiology: direct actions of melatonin on fetal cerebral artery, brown adipose tissue and adrenal gland. J Physiol 586.16, 4017-4027

Uppenborn W. (1933) Untersuchungen über die Trächtigkeitsdaver der Stuten, mit einem Anhang: Untersuchungen über Zwillinsgeburten beim Pferd. Zeitschrift für Tierzüchtung und Züchtungsbiologie einschließlich Tierernährung 28, 1-27

Valera M., Blesa F., Dos Santos R., Molina A. (2006) Genetic study of gestation length in andalusian and arabian mares. Anim. Reprod. Sci. 95, 75-96

Vandeplassche M. M. (1986) Delayed embryonic development and prolonged pregnancy in mares. In: Current therapy in theriogenology, Morrow D. A. Editor, 2nd Ed., WB Saunders, Philadelphia, USA, 685-689

Williams L. M., Hannah L. T., Adam C. L., Bourke D. A. (1997) Melatonin receptors in red deer fetuses (Cervus elaphus). J. Reprod. Fertil. 110, 145-151

Wilsher S., Allen W. R. (2003) The effects of maternal age and parity on placental and fetal development in the mare. Equine Vet. J. 35, 476-483

Wilsher S., Lefranc A. - C., Allen W. R. (2012) The effects of an advanced uterine environment on embryonic survival in the mare. Equine Vet. J. 44, 432-439

Winter G. H. Z., Rubin M. I. B., De La Corte F. D., Silva C. A. M. (2007) Gestational length and first postpartum ovulation of Criollo mares on a stud farm in Southern Brazil. J. Equine Vet. Sci. 27, $531-534$

\section{Zusammenfassung}

Ziel dieser Studie war es, Faktoren zu untersuchen, die die Trächtigkeitsdaver (gestation lenght - GL) bei Finnpferden (FH) und amerikanischen Standardbreds (SB) beeinflussen. Hierbei wurde der Reproduktionsstatus der Stute besonders berück-sichtigt. Die Daten aus 15 Zuchtjahren (1991-2005) wurde von Suomen Hippos, der finnischen Trab- und Zuchtvereinigung, zur Verfügung gestellt. Aus den Daten geht hervor, dass 8952 Trächtigkeiten von 3649 SB Stuten und 4579 Trächtigkeiten von 2149 FH Stuten folgende Kriterien erfüllten: künstliche Besamung (Al), entweder mit frischem oder transportiertem Sperma, ein lebensfähiges Fohlen und eine GL von 300-390 Tagen (letzte Al bis Geburt). Die Auswirkungen auf die GL von Rasse, Alter und Reproduktionsstatus der Stute (maiden, güst, pausierend oder Fohlen bei Fuß) zu Beginn der Paarungszeit, Parität, Monat und Jahr der Paarung, Hengststation und Geschlecht des Fohlens wurden mittels linearer gemischter Modelle bestimmt. Alle Modelle wurden unter Verwendung der verbleibenden Maximum Likelihood Schätzung ermittelt. Die GL bei Stuten mit Fohlen bei Fuß war signifikant kürzer als bei maiden, güsten oder pausierenden Stuten (SB : $\mathrm{P}<0,0001 ; \mathrm{FH}: \mathrm{P}<0,01)$. Bei maiden, güsten und pausierenden Stuten waren die Trächtigkeitszeiten ähnlich. Der Paarungsmonat hatte einen signifikanten Einfluss auf die $G L(P<0,0001)$. Die längsten und kürzesten Trächtigkeiten wurden bei Stuten, die im April beziehungsweise im August besamt worden waren, gefunden. Die SB Stuten, die im Februar bis März besamt worden waren, wiesen kürzere Trächtigkeiten auf als Stuten, die im April besamt worden waren $(P<0,01)$. Die FH Stuten trugen ihren Fohlen signifikant länger (bereinigter Mittelwert 334,8 Tage, 95\% Konfidenzinterval 334,2-335,5) als SB Stuten (bereinigter Mittelwert 331,7 Tage, 95\% Konfidenzinterval 331,2-332,3 Tage) ( $P<0,0001)$. Bei beiden Rassen hatten Primipara längere Trächtigkeiten als Multipara $(P<0,0001)$. Die GL zwischen verschiedenen Altersgruppen unterscheiden sich nicht bei den SB Stuten, aber junge FH Stuten trugen 2,3 Tage kürzer als sehr alte Stuten $(P<0,05)$. Hengstfohlen wurden bei beiden Rassen 1,8 Tage länger als Stutfohlen getragen $(P<0,0001)$. Zusammenfassend ist festzustellen, dass bei Standardbreds die Beziehung zwischen Besamungsdatum und Trächtigkeitslänge positiv von März bis April und negativ von April bis August war. Die kurze mittlere GL der SB Stuten in Finnland unterstützt die Annahme, dass der Breitengrad die GL beeinflusst. Der Reproduktionsstatus der Stute zum Zeitpunkt der Al hatte einen signifikanten Einfluss auf die GL. Dieser Befund legt nahe, dass das Uterusmilieu in der frühen Trächtigkeit die Länge der Trächtigkeit beeinflussen kann.

Schlüsselwörter: Pferd / Trächtigkeitsdaver / Trächtigkeit / Breitengrad / Jahreszeit / Reproduktion 


\title{
Morphofunctional characteristics of the equine endometrium during spring and autumn transition
}

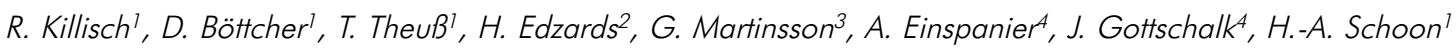 \\ 1 Institut für Veterinär-Pathologie, Universität Leipzig, Germany \\ 2 Tierärztliche Praxis Edzards, Hinrichs, Rüth, Esens/Ostfriesland, Germany \\ 3 Niedersächsisches Landgestüt Celle, Germany \\ ${ }^{4}$ Veterinär-Physiologisch-Chemisches Institut, Universität Leipzig, Germany
}

Correspondence: Richard Killisch, Institut für Veterinär-Pathologie, Universität Leipzig, An den Tierkliniken 33, 04103 Leipzig, Germany E-Mail: richard.killisch@vetmed.uni-leipzig.de

\section{Introduction}

On average, the physiological breeding season of the mare comprises the months May until October in the northern hemisphere. The remaining months constitute the anoestrus period, which can be divided into three phases. The autumn transitional period (ATP), the deep anoestrus phase during the winter months and the spring transitional period (STP). Due to many varying factors such as body weight, age, ovarian activity, lighting conditions, temperature and nutrition, it is hardly possible to determine the exact date and length of both the STP and ATP. Dates that can be found in the literature range from February to early May regarding the STP. The earliest onset of ATP is supposed to be in September, whereas the latest date of ending has been stated to be in December. The transitional period in spring has a variable length ranging from 30 to 90 days. It is yet more extensively examined and documented than its counterpart in autumn. However, detailed investigations of the endometrial morphology have not been carried out so far. This study depicts a first morphological characterization of the equine endometrium during the spring as well as the autumn transitional period.

\section{Materials and methods}

Endometrial specimens of mares with detailed clinical documentation were mainly obtained from routine biopsy submissions sent to the Institute of Pathology of the University of Leipzig $(n=264)$. In addition, endometrial samples were taken from 7 mares that were euthanized or had died spontaneously and were submitted for necropsy at the same department. Specimens taken in February, March and April were selected to outline the spring transitional period, whereas samples taken in September, October and November were chosen to investigate the autumn transitional period. These relatively long spaces of time had been determined in order to span the great diversity of dates found in the literature regarding the duration of the transitional periods. All samples were fixed in $4 \%$ neutral buffered formalin for at least 24 hours, embedded in paraplast, sectioned at 3-4 $\mu \mathrm{m}$ and stained with hemalum and eosin (H.-E.). The samples were then examined microscopically with special emphasis on the functional morphology of the endometrium (activity, glandular and stromal differentiation), ascertained according to Kenney and Doig (1986) and Schoon et al. (1992, 1997). In cases where a regular endometrial functional morphology was lacking, the different types of maldifferentiation were classified according to Häfner et al. (2001).

\section{Results}

In this study, a total number of 271 samples of endometrial tissue from mares during the ATP $(n=77)$ and STP $(n=194)$ were examined. During STP, a predominantly absent or low endometrial activity was seen until early April. In ATP, no or only low activity could be detected in more than $60 \%$ of all specimens from late October onwards. About $24 \%$ of all evaluated specimens (summarizing STP and ATP) showed an 'irregular' endometrial differentiation, i.e. their functional morphology was classified as 'irregular secretory' and 'irregular proliferative', respectively. In contrast, in less than $3 \%$ of all endometrial samples an 'unequal proliferative' differentiation could be detected. Accordingly, only about $10 \%$ of all maldifferentiated endometria showed an 'unequal' functional morphology, whereas the vast majority (90\%) was classified to be differentiated 'irregularly'. In one specimen parts of an 'unequal proliferative' as well as parts of an 'irregular proliferative' differentiation were seen. The specimens taken during STP exhibited differentiation disorders ranging between $24 \%$ and $35 \%$ in February and March, with a maximum in late February. In April, the percentage of endometrial maldifferentiation declined to about $17 \%$ (first half of April) or even lower (13\%, in the second half of the month).

Comparing the appearance of these disorders in ATP, an increase from about $14 \%$ in late September to nearly $45 \%$ in the first half of November could be observed. At the 'margins' of the period which was examined to outline the ATP, results differing from this phenomenon were obtained. The first half of September deviated from the straight increase mentioned above, since about $33 \%$ of maldifferentiated endometria could be detected during these two weeks. In contrast to the high percentage of endometrial disorders occurring in early November, the rate of maldifferentiation declined beneath $30 \%$ in the second half of the month. A comparison of the endometrial functional morphology with the clinically evaluated ovarian status showed, that these findings were in accordance in about $60 \%$ to nearly $80 \%$ of all mares examined during STP. Similarly, consistence of these parameters occurred in nearly $60 \%$ to almost $70 \%$ of the cases investigated in ATP.

\section{Discussion}

In the present study, almost $71 \%$ of all samples were taken during the STP. This unequal distribution of the specimens regarding the examined periods might be due to several facts. On the one hand, the rigorous selection criteria regarding a detailed clinical anamnesis led to the exclusion of plenty of biopsies received for routine diagnostic issues. On the other hand, it reflects the annual seasonality of biopsy samples being submitted for routine examination. The latter fact confirms the pronounced economic interest and points out its 